\title{
IdeAs
}

Idées d'Amériques

17 | 2021

Villes et culture dans les Amériques

\section{Cities and culture in the Americas}

The divide between cultural "capitalism" and the cultural practice of city dwellers

\section{Diana Burgos-Vigna and Cynthia Ghorra-Gobin}

Translator. Michael Hinchliffe

\section{CpenEdition \\ Journals}

\section{Electronic version}

URL: https://journals.openedition.org/ideas/11208

DOI: $10.4000 /$ ideas. 11208

ISSN: 1950-5701

\section{Publisher}

Institut des Amériques

\section{Electronic reference}

Diana Burgos-Vigna and Cynthia Ghorra-Gobin, "Cities and culture in the Americas", IdeAs [Online], 17। 2021, Online since 01 May 2021, connection on 04 June 2021. URL: http://journals.openedition.org/ ideas/11208; DOI: https://doi.org/10.4000/ideas. 11208

This text was automatically generated on 4 June 2021.

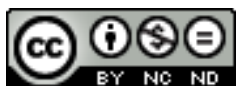

IdeAs - Idées d'Amériques est mis à disposition selon les termes de la licence Creative Commons Attribution - Pas d'Utilisation Commerciale - Pas de Modification 4.0 International. 


\title{
Cities and culture in the Americas
}

The divide between cultural "capitalism" and the cultural practice of city dwellers

\author{
Diana Burgos-Vigna and Cynthia Ghorra-Gobin
}

Translation : Michael Hinchliffe

1 In western tradition, culture is one of the major attributes of cities (Benevolo L., 1983). Culture shapes cities with buildings that carry aesthetic and historical value, with networks of streets, avenues and boulevards for transport and general mobility, and, sometimes, with fine vistas that offer so many occasions for outings and intercourse. But culture is in return shaped by the city in so far as the city's monuments and layout help to mold urban modes of life, urban rituals, manners and mentalities.

In today's circumstances, informed by general and specific globalization ${ }^{1}$ in the wake of the digital revolution, cities are continually changing to accommodate the worldwide flow of cultural and economic shift. The philosopher Olivier Mongin (2013) has suggested the term "flow city" (ville des flux) to designate cities that contribute to the circulation of ideas, information and cultural practices by adopting large-scale urban development projects, by hosting international cultural events or simply by transforming public space in transitional districts. Such change does not occur exclusively in world, or so-called "superstar", cities (Sassen S.,1996), but also in secondary cities (Hodos J., 2015) which, though they participate in both types of globalization, have no commandeering economic role. Culture, then, can be called upon to bolster a city's appeal for prospective investors, entrepreneurs, cultural creators and tourists. It is part and parcel of the new phase of capitalism known as cultural capitalism (Harvey D., 2014).

In the Americas, cities are also transformed under the pressure of migratory flux. Over the last two decades, English and American researchers have been studying changes (mural art, new uses of public space) brought about by the arrival Latin-American people. Sociologist Mike Davis (2000) calls this reinvention of the city by Latinos Magical Urbanism. More recently, the historian Andrew K. Sandoval-Strausz in his study Barrio America (2019) identifies Latino immigrants as having saved the city in the US. In other words, the cultural practice of Latinos, the way they have brought new value to public 
spaces through murals and street art, has regenerated cities. This is a "bottom up" dynamic, initiated by social actors, inhabitants or artists themselves, as opposed to "top down" policies instrumentalizing culture for the benefit of attractivity strategies. This issue of IdeAs proposes an exploration of these two types of dynamic, on the one hand culture subordinate to policies of city-branding producing new urban development and international events, on the other, culture as the hallmark of a mobilization of social forces tending towards the elaboration of an urban narration the tonality of which is cultural plurality.

\section{Culture instrumentalized: policies of attraction}

Initial research on the consequences of globalization (<mondialisation and <globalisation) focused on the risk of the US model influencing national and urban cultures, the danger of a cultural Americanization of the world (Guéhenno J.-M., 1999; Tournès L., 2020). This approach is however criticized by researchers adopting a cultural studies perspective who consider globalization [<mondialisation] as a process whereby cultural diversity is made visible, whether on world or city scale. The anthropologist Arjun Appadurai at the University of Chicago has evidenced the principle of cultural diversity as a result of the phenomenon of migration coupled with collective imagination ${ }^{2}$. However, it was most certainly the study by geographer and economist Richard Florida, The Rise of the Creative Class (2002) that most influenced urban actors, both political and economic.

Florida describes the rise of a new social class he calls the "creative class" because of its inventiveness in fields as diverse as artistic activities, finance, the media, high technology and other sectors. Members of this creative class head for cities which both display a culture of tolerance with respect to cultural diversity (Tolerance-TechnologyTalent) and provide a cultural offer of quality. Thus cultural amenities are seen as an attractivity-boosting factor. Florida's thesis has powerfully influenced local decision makers who, wishing to consolidate their city's position in the flux of globalization [<mondialisation and <globalisation], have conducted ambitious cultural policies involving the revalorization of historical heritage, the building of new concert venues, the creation of new museums and galleries or the refurbishment of older ones, the organization of salons and other events, not to speak of large-scale urban projects such as the construction of new residential districts under the denomination of eco-districts. Cultural policy is here part of an attractivity strategy aimed at the creative classes, together with investors and tourists. While Florida's analysis does not single out tourists, decision-makers have done so, giving them considerable importance.

6 In the knowledge-based economic development characteristic of the contemporary situation, urban policy is indissociable from cultural policy (Landry C., 2008). Though this can be seen as an advance in that culture is valorized, the instrumentalization of culture within the terms of a strategy of attractivity risks excluding a section of the population, the popular classes, and leading to a process of gentrification favorable to the rich and connected. 


\section{Culture, inhabitant-based practice and the right to the city}

7 Another way of looking at culture in cities is to shift the pointer to the micro-local level and examine cultural practice there. Doing that means seeing culture not as a political, economic or symbolic resource to the scale of the city as a whole, but rather as a collective product, even as a tool of transformation and empowerment in the hands of the inhabitants themselves. This type of analysis is in alignment with those who have seen the city as a space modeled by the people leading their daily lives within it, changing it at times, modifying the way they use it. This, indeed, was the conception developed by Henri Lefebvre in the 60s. Lefebvre defined the right to the city as "a superior form of right: the right to liberty, to individualization within socialization, the right to a dwelling and to actually dwell. The right to engage (in participative activity) and the right of appropriation (clearly distinct from the right to property) are implicated in the right to the city" (Lefebvre H., 1967: 125). Following Lefebvre, theorists of radical, and later, critical geography spoke out against urban evolutions favoring values of commercial or real-estate exchange as opposed to values of use, that is the possibility of actually practicing the city, of coming together there with others, of expressing individual and collective liberty (Brenner N., Marcuse P., Mayer M., 2012).

8 Theories of the right to the city have been influential on urban policy and the place of culture in the Americas. Urban studies in Latin America took them on board at the very outset of the $21^{\text {st }}$ century, opening the way for debates stretching far beyond the confines of academia (Burgos-Vigna D., 2020). Several countries adopted the notion by including it in their constitutional texts ${ }^{3}$ or more locally in urban charters ${ }^{4}$. As applied to the cultural sphere, it allows emphasis on ideas of participation, of co-construction and cultural diversity. Decolonial studies also seized upon the notion to critique the domination undergone by Indian, Afro-descendant, or mixed race cultures, often belittled or shoved into invisibility, given voice only through the folklorization of certain more "consensual" characteristics (Quijano A., 2012).

The early years of the $21^{\text {st }}$ century saw a rapid diffusion of this type of orientation that was fueled by new strategies being evolved in international organizations such as the International Development Bank as far as urban policy was concerned (Rojas E., 2009) or UNESCO in the strictly cultural sphere (UNESCO, 2003; 2005). Without excluding the idea of culture developed as a major economic resource, these organizations place greater emphasis on the participation of local populations in the preservation of their culture(s), sometimes in the elaboration of their identity narratives; they valorize immaterial cultural heritage, speak in terms of "living" heritage, of cultural diversity and sustainability. Such language is notably to be found at the source of the "políticas de mejoramiento barrial" (district improvement policies) conducted over the last years in Latin American cities at micro district or street level. Such programs articulate a vision of culture as a tool for social, urban development, or indeed, as "the fourth pillar of sustainable development" (UCLG, 2010).

However, these policies are not always immune to the risks of instrumentalization and approprition mentioned in the first part of this introduction. Street art is an emblematic example here. Although it is by definition a transgressive art form, taking possession of urban spaces not initially set aside for such a use, it does not escape 
subversion when its aesthetic is taken over by local authorities in order to valorize one outlying district or another (Schacter R., 2014).

11 Does this mean that urban cultures should no longer be counted as autonomous expression in public space? Although art and culture are indeed taken up in the conflicts surrounding urban spaces and find themselves at the heart of the interplay of interests between elites, local authorities and inhabitants, it would be a mistake to underestimate their democratic potential. Olivier Dabène for one sees street art as a possible avenue of democratization in contexts where traditional means of participation are exhausted. It is, he argues, an art form that contributes to the renewal of our democracies by virtue of the public debate, the increased level of awareness, indeed, the emotion to which it gives rise (Dabène O., 2020). Whether it has to do with the "power to act", or, on a more day to day basis, with interpersonal encounters, the question of democracy arises in the same manner with all the cultural practices to be found in cities in the Americas, from popular theater to exhibitions and performances or all sorts via cultural theme parks or, quite simply, the access to certain public spaces. As anthropologist Nestor García Canclini puts it, "the preservation of cultural commodities can never come before the preservation of the people who need those commodities to live their lives" (1999: 28). As far as cultural practice is concerned, it is indeed a matter of moving from cities to sightsee in towards cities to live in, from spectacle or museum cities towards shared urban spaces.

\section{Convergence between questions raised in the cities of South and North America}

12 The studies presented here all deal with the place of culture in cities in the Americas. Some look at the tension between culture as perceived by economic and political elites and culture as perceived by inhabitants; others portray the richness and creativity of urban life as expressed through culture. They raise questions about local cultural policies or the everyday life of city-dwellers:

13 - How do certain cultural spaces become loci of contestation and resistance in contexts of political crisis? Mélanie Toulhoat relates how the International Humor Exhibition of Piracicaba provided a rich observatory of cultural policy at the time of Brazil's democratic transition, both as a local reflection of national developments and as a circle of free expression in a situation of repression. Lucía Durán also explores the subject of mobilization and contestation in her piece on the city of Quito where, in a time of crisis, heritage concerns become a source of conflict but also of new appropriations. The current pandemic also induces the question of a sightseeing city without sightseers.

14 - What sort of link is forged between a work of urban performance and the public, or different types of public? How do cultural works chosen by elected political representatives give rise to arguments, or even conflicts, anchored in social issues? The piece by Suzanne Paquet and Laurent Vernet looks at the controversy over the reception of the Vélocité des lieux art installation in the north end of Montreal and analyzes it in terms of the difficulty in defining the public targeted, a public including the ordering body and the artists themselves hoping to achieve "an urban light event" and a local population unaccustomed to public art installations of that nature. 
15 authorities help to reconfigure actual urban spaces? Pascale Nédelec studies the transformation of the hitherto automobile-centered tourist area of Las Vegas into a space for tourists on foot. The transformation of urban areas is also examined by Catherine Paquette and Luis Campos Medina in their study of the effect of cultural programs initiated by local or national authorities in several Latino-American cities. They draw up a typology integrating impact both on public space and on the social tissue of the districts affected. defined as "cognitive capitalism" by Marxist oriented geographers? Simon Renoir subscribes to this hypothesis in his analysis of how private sector actors have revitalized the town center of Detroit, a city emblematic of demographic and economic decline. The discursive performance of culture has indeed brought about a social and spatial reconfiguration of the city, but it has also had the effect of making cultural practices involving street art invisible by confining them to outlying districts of the city. Aline Hémond also looks at the subject of street art but in Chicago. She shows how the appropriation of public spaces by Latinos has led to a gentrification of the Pilsen neighborhood and with it a greater attractivity for tourists that has not come without problems for the local inhabitants.

17 - How is it that the objective of developing tourism in a small US city has meant disqualifying native American inhabitants from the city center and relegating them to the outskirts? Céline Planchou and Sandrine Baudry demonstrate the contradiction unresolved by the local authorities of Rapid City (Dakota) who lay claim, on the one hand, to a native American history while, on the other, disallowing any Indian presence in the tourist town center.

18 - Cultural practices are levers of empowerment, or of access to local citizenhood. Several articles here explore these avenues. One example is the study of theater in the favelas conducted by Fanny Arnulf. How does culture contribute to the feeling of belonging in a community? Barbara Morovich on the southern districts of Buenos Aires and Baptiste Mongis on the Bolivian cities of La Paz and El Alto both show how urban policies set in motion by local authorities result in a mixture of interactions with inhabitants, varying from tension to negotiation.

19 The cities studied here are not chosen for any exceptional or exemplary characteristic they may possess. Most of them are "ordinary cities" (Robinson J., 2006). Presenting them in crisscross fashion helps move away from preset categories and received, frequently deceptive, hierarchizations, such as South or North cities, Latin-American or Anglo-American cities, developing or rich cities. To take culture as the base reference is to subscribe to Raymond Barthes' assertion that the city is "where the encounter with otherness occurs" (Barthes R., 1991); it also means highlighting what it is that makes each of the places under study singular, a place of conflict perhaps, but a place where a multiplicity of urban experience may find expression. 


\section{BIBLIOGRAPHY}

Appadurai, Arjun, Après le colonialisme : les conséquences culturelles de la mondialisation, Paris, Payot, 2015.

Barthes, Roland, L'aventure sémiologique, Paris, Seuil, 1991.

Benevolo, Leonardo, Histoire de la ville, Fribourg, Éditions Parenthèses, 1983.

Bourdieu, Pierre, La Distinction. Critique sociale du jugement, Paris, Ed. de Minuit, coll. Le Sens Commun, 1979.

Brenner Neil, Marcuse, Peter et Mayer, Margit, Cities for People, Not for Profit: Critical Urban Theory and the Right to the City, New York et Londres, Routledge, 2012.

Burgos-Vigna, Diana, « Le droit à la ville et ses passages transatlantiques », Revue Pandora, Université Paris 8, $n^{\circ}$ 15, 2020, p.141-154, https://etudes-romanes.univ-paris8.fr/IMG/pdf/ pandora15_interactif.pdf, page consultée le 12 février 2021.

Darchen, Sébastien \& Diane-Gabrielle, Tremblay, « La thèse de la classe créative : son incidence sur l'analyse des facteurs d'attraction et de la compétitivité urbaine », Revue Interventions Économiques/Papers in Political Economy n 37, 2008,

https://journals.openedition.org/interventionseconomiques/503, page consultée le 11/01/2021.

Carrel, Marion, Faire participer les habitants? Citoyenneté et pouvoir d'agir dans les quartiers populaires, Lyon, ENS éditions, 2013.

CGLU (Ciudades y Gobiernos Locales Unidos), La cultura es el cuarto pilar del desarrollo sostenible, $3^{\mathrm{e}}$ Congrès Mondial, México, 2010.

Ghorra-Gobin, Cynthia (dir.), Dictionnaire critique de la mondialisation, Paris, Armand Colin, 2012.

Dabène, Olivier, Street Art and Democracy in Latin America, Londres, Palgrave Macmillan, 2020.

Davis, Mike, Magical Urbanism, Londres, New York, Verso, 2000.

Florida, Richard, The Creative Class: And How It's Transforming Work, Leisure, Community and Everyday Life, New York, Basic Books, 2002.

García Canclini, Néstor, « Los usos sociales del patrimonio cultural », in Ernesto Aguilar (dir.), Patrimonio Etnológico. Nuevas perspectivas de estudio, Consejería de Cultura-Junta de Andalucía, 1999, p. 16-33.

Guehenno, Jean-Marie, « Américanisation du monde ou mondialisation de l'Amérique », Politique étrangère, 1999, 64-1, p. 7-20.

Harvey, David, « Vers la ville entrepreneuriale. Mutation du capitalisme et transformations de la gouvernance urbaine ", in Cécile Gintrac et Mathieu Giroud (dir.), Villes contestées, Ed. Les prairies ordinaires, 2014, p. 125.

Hodos, Jerome, " Globalization and the Concept of the Second City ", City \& Community, vol. 6 \#4, 315-333, 2007, https://journals.sagepub.com/doi/full/10.1111/j.1540-6040.2007.00230.x, page consultée le $21 / 12 / 2020$.

Jacobs, Jane, Death and Life of the American City, New York, Random House USA Inc., 1961.

Quijano, Anibal, «Bien Vivir : entre el desarrollo y la des/colonialidad del poder », Viento Sur, $n^{\circ} 122,2012$, p. 46-56. 
Landry, Charles, The Creative City, New York, Londres, Routledge, 2008.

Lefebvre, Henri, Le Droit à la Ville, Paris, Anthropos, Ed. 2009 (1 1 ère édition en 1967)

Mongin, Olivier, La ville des flux, Paris, Fayard, 2013.

Robinson, Jennifer, «Villes ordinaires : vers des études urbaines post-coloniales », in Cécile

Gintrac et Mathieu Giroud (dir.), Villes contestées, Paris, Les Prairies Ordinaires, 2014 (traduction d'un texte de 2006), p. 35-55.

Rojas, Eduardo (dir.), Construir Ciudades, mejoramiento de barros y calidad de vida urbana, Washington DC, BID, 2009.

Sandoval-Strauz, Andrea K., Barrio America, Basic Books, 2019.

Sassen, Saskia, La ville globale. New York, Londres, Tokyo, Paris, Descartes \& Cie, 1996.

Schacter, Rafael, « The ugly truth: Street art, Graffiti and the Creative city », Art and The Public Sphere, vol. 3, n², 2014, p. 161-176.

Supiot, Alain, Mondialisation ou globalisation? Les leçons de Simone Weil, Paris, Collège de France, coll. « Conférences », 2019.

Tournès, Ludovic, Américanisation. Une histoire mondiale. XVIII ${ }^{e}-\mathrm{XXI}{ }^{e}$ siècles, Paris, Fayard, coll.

«L'épreuve de l'histoire », 2020.

UNESCO, Convention pour la Sauvegarde du patrimoine culturel immatériel, Paris, 17 octobre 2003.

UNESCO, Convention sur la protection et la promotion de la diversité des expressions culturelles, Paris, 20 octobre 2005.

\section{NOTES}

1. This article adopts the differentiation between types of globalization described in the Dictionnaire critique de la mondialisation (Ghorra-Gobin C., 2012) and in the work of Alain Supiot (2019). General globalization (Fr mondialisation) refers to the greater intensity of exchange and relationships worldwide, whereas specific globalization (Fr globalisation) concerns the circulation of capital, the financialization of capitalism and neoliberal policy.

$N d T$. To obviate the problem arising from the existence in French of two terms, mondialisation and globalisation, as opposed to the single term "globalization" available in English, the present translation specifies where necessary which French term is concerned at each occurrence as follows: globalization [<mondialisation]; globalization [<globalisation].

2. Appadurai's 1996 work Modernity at Large: the Cultural dimensions of Globalization has a French translation under the title: Après le colonialisme. Les conséquences culturelles de la globalisation. Payot, 2001.

3. Brazil in 2001; Ecuador in 2008.

4. World Charter for the Right to the City (Quito, 2004), Mexico City Charter for the Right to the City (2010). 


\section{AUTHORS}

\section{DIANA BURGOS-VIGNA}

Diana Burgos-Vigna est professeure en études latino-américaines à l'Université Paris Nanterre et membre du laboratoire CRIIA où elle est responsable du GRECUN (Groupe État Culture Nation dans le monde ibéro-américain). Ses recherches portent principalement sur les villes sudaméricaines et s'articulent autour de trois axes principaux : la démocratie participative, les réseaux de villes, et les politiques culturelles et patrimoniales locales.

\section{CYNTHIA GHORRA-GOBIN}

Cynthia Ghorra-Gobin CNRS-Iheal, Université Sorbonne Nouvelle, est géographe et membre du laboratoire CREDA (Centre de recherche et de documentation des Amériques). Ses recherches qui portent principalement sur les villes nord-américaines sont centrées sur les transformations spatiales et culturelles de la ville en relation avec la mondialisation et la globalisation. Elle a coordonné les deux éditions du Dictionnaire critique de la mondialisation, Armand Colin, 2006 et 2012. 